\title{
Factors' Affecting the Motives of Rural Households' Saving Behavior in North Bench District, Bench Maji Zone of Southern Ethiopia
}

\author{
Alemayehu Gonosa $^{1} \quad$ Baynachew Bargissa $^{2} \quad$ Kidane Tesfay $^{2}$ \\ 1.Department of Agricultural and Resource Economics, Mekelle University, Ethiopia \\ 2.Department of Rural Development and Agricultural Extension, Mekelle University, Ethiopia
}

\begin{abstract}
A few studies conducted in Ethiopia about rural household's saving behavior devoting much attention to macroeconomic data. Therefore, this paper examines both motives of rural household's saving and factors affecting their saving behavior by using micro level data sets. Primary data were obtained from structured and semi-structured questionnaire, key informants interview, field observation and focus group discussion whereas the secondary data were gathered from banks and micro-finance institutions. A multistage sampling technique was used to select the study area and178 sample respondents. The descriptive statistical tools including frequencies and percentages were used to examine motives of rural household's saving whereas chi-square test and t-test were used to examine statistical significance between dependent and explanatory variables. In addition, binary logit model was used to analyze factors affecting rural household's saving behavior. Results show that mitigating emergency, smoothing future consumption, high interest rate, planning to have luxury life and starting new business were reasons behind the motives of rural household's saving whereas lack of surplus income, shortage of formal financial institutions, lack of awareness and low interest rate were discouraging factors to save in the area. Furthermore, Age, education level, access to credit and extension service, interest rate, transaction cost and livestock ownership of household heads were factors significantly influencing rural household's saving behavior . Giving emphasis on adult education, income diversification, expanding branches of formal financial institutions, proving extension service and revising interest rate were points recommended to all concerned bodies to enhance rural households saving behavior in the study area.
\end{abstract}

Keywords: Factors affecting, rural households, saving behavior, North Bench District

DOI: $10.7176 / \mathrm{JESD} / 11-17-04$

Publication date:September $30^{\text {th }} 2020$

\section{Introduction}

\subsection{Background and Rational of the Study}

The primary objective of the world's countries in general and the developing countries in particular was to achieve intergenerational economic growth where domestic (national) saving plays critical role in capital accumulation (Jagadeesh, 2015). In developing countries where income prospects are much more uncertain for most households, saving is not only about accumulation for future consumption but also about consumption smoothing in the face of volatile incomes (Athukorala and Tsai, 2003; Abdelkhalek et al., 2009). It is researched that household savings could provide them financial security even during retirement time where the money saved would be used for a house down payment, or for children's education (Rha et al., 2006; Yao et a., 2011).

In most developing and developed countries, household saving constitutes the biggest proportion of total domestic savings. For example, in the developed countries saving ratio lies from $15 \%$ to $20 \%$ and individual savings account from $10 \%$ to $15 \%$ (Saqib, 2016). This low level of rural households saving behavior in formal financial institution in least developed countries was mainly due to high level of unemployment, low level of income, and high economic fluctuations induced by climate change related shocks (Karim, 2010; Tsega and Yemane, 2014).

To upgrade this low level of saving behavior in developing nations, it is much important to deal with the saving motives of rural households (Remble et al., 2013). It is also vitally important to input the households with the importance of saving for their future life (Haron et al. 2013). There is also a need to understand that different countries hold different motives to save. For example, the top three motives of household saving in Australia are retirement (life-cycle motive), holidays, and a rainy day (precautionary motive) (Harris et al., 1999). The very recent works of scholars investigated that households carry a number of motives to save their money (Shin et al., 2019; Carmen de et al., 2018). According to the scholars' findings, lower income households save for lower level needs i.e. daily expenses, while high income households save for higher needs such as investment. It is also investigated that saving for an emergency, saving for future smooth life and saving for children education as top dominant motivating factors forcing households to save their money (Shin et al., 2019; Carmen de et al., 2018; Tariku, 2018).

Second to recognizing motivating factors, this paper also initiated to examine factors affecting household's 
saving behavior. These factors are almost the same in most world countries. For example, a study conducted in Pakistan by (Sherani et al., 2014) on the household savings behavior showed that children education expenditure, family size, value of house and liabilities to pay are variables significantly make households less likely to save. Similarly, (Usman et al., 2016) have carried out a study on the determinants of households saving in both urban and rural areas of Pakistan. Results show that income, age and employment had a significant and positive association with household savings whereas education had significant negative association with household savings in both areas. Viewed differently, in India both in long run and short run, the dependency ratio, interest rate and inflation have statistically significant influence on household savings (Samantaraya and Patra, 2014). In Africa, (Asare et a., 2018), conducted a research on understanding the savings behavior of households by modeling the savings behavior of households in Ethiopia, the results of the study reveal that the number of extension contacts, land holding size and access to market information have significant positive effects on the likelihood that a household would save.

From economic analysis view point, income, age (savings increases with age and tends to decline after crossing a certain age limit) sex, marital status, forms of institutions used for saving and frequency of getting money are significant determinants of household savings (Mirach and Hailu, 2014; Tenzin, 2013) whereas household expenditures and farm input price were negatively influence the saving capacity of rural households (Mossie and Tadele, 2018). Recent works signified abundantly that the low level of household savings which has kept national saving status below standard has also negatively contributed to the country's GDP growth and job opportunity creations (Mossie and Tadele, 2018; African economic outlook report, 2017). This low individual and national saving culture has been affecting the top three motives (to meet emergency needs (76\%), invest in nonfarm business sector (64\%) and invest in human capital (26\%) for rural household saving in Ethiopia (EDRI, 2012).

Empirical studies curried out at national level, particularly in southern nations nationalities and peoples regional state of Ethiopia where the current study area is not an exception, abundantly and significantly indicated that age, educational level, livestock holdings, access to credit service, income of household, marital status, farm and off-farm income, occupation and land size significantly and positively affecting the household saving (Bedemo et al. 2017; Abera, 2017; Fenta et al., 2017; Kassa et al., 2013; Bealu, 2018; Nigus, 2015; Gedela 2012). In the other side, people do not save due to reasons such as lack of adequate annual earnings, high living expenses and lack of good and adequate saving awareness (Tariku, 2018).

In Ethiopia, several studies evidenced that the culture-bounded and the blow standard saving habit has positively forced Ethiopia to depend on foreign countries financial aid (Nayak, 2013; Mirach and Hailu, 2014; Kifle, 2012). Smoothly supporting this evidence, (Aron et al., 2013) discovered that from the country level, only about six million rural households save their money income in the formal financial institutions whereas only three towns in Ethiopia (Hawasa, Mekelle and Addis Ababa) have had regular saving or save their money income in the formal financial institutions.

From all the reviewed literatures at national level, it could be clearly seen that majority of the works (Bedemo et al. 2017,; Abera, 2017; Fenta et al., 2017; Kassa et al., 2013; Bealu, 2018; Nigus, 2015; Gedela 2012; Kifle, 2012) have been done on the motives and factors affecting rural households saving behavior on the bases of aggregate or macroeconomic data that do not give due attention on micro level saving behavior of rural poor households in Ethiopia. This dearth of micro-level information therefore has initiated to undertake this study in North Bench district of Bench Maji Zone, Ethiopia aiming to examine the motives of household saving and the factors that have been influencing their saving behavior in the area.

\section{Methodology of the Study}

\subsection{Description of the Study Area}

North Bench district is located in Bench-Maji zone of Southern Nations, Nationalities and Peoples' Regional State, Ethiopia at about $508 \mathrm{kms}$ Southwest of Addis Ababa. According to annual report from the district's Administration Office (2019), the district has 30 villages among which 27 are rural villages. Geographically, the district lies between $35^{\circ} .52$ ' 53.03 " and $35^{\circ} 72^{\prime} 85.12^{\prime \prime} \mathrm{E}$ and $6^{\circ} 91^{\prime} 57.76^{\prime \prime}$ and $7^{\circ} 20^{\prime} 86.80^{\prime \prime} \mathrm{N}$. The altitude of the district ranges from 1153 to $2696 \mathrm{~m}$.a. s. 1 and the slope ranges from $13.42 \%$ to $131.69 \%$ as it calculated from digital elevation. According to the BoFED (2012) annual statistical abstract data of SNNPR, the total population of the district is 130,000 among them 77260 are males and 52740 are females. 


\section{Map of study area}
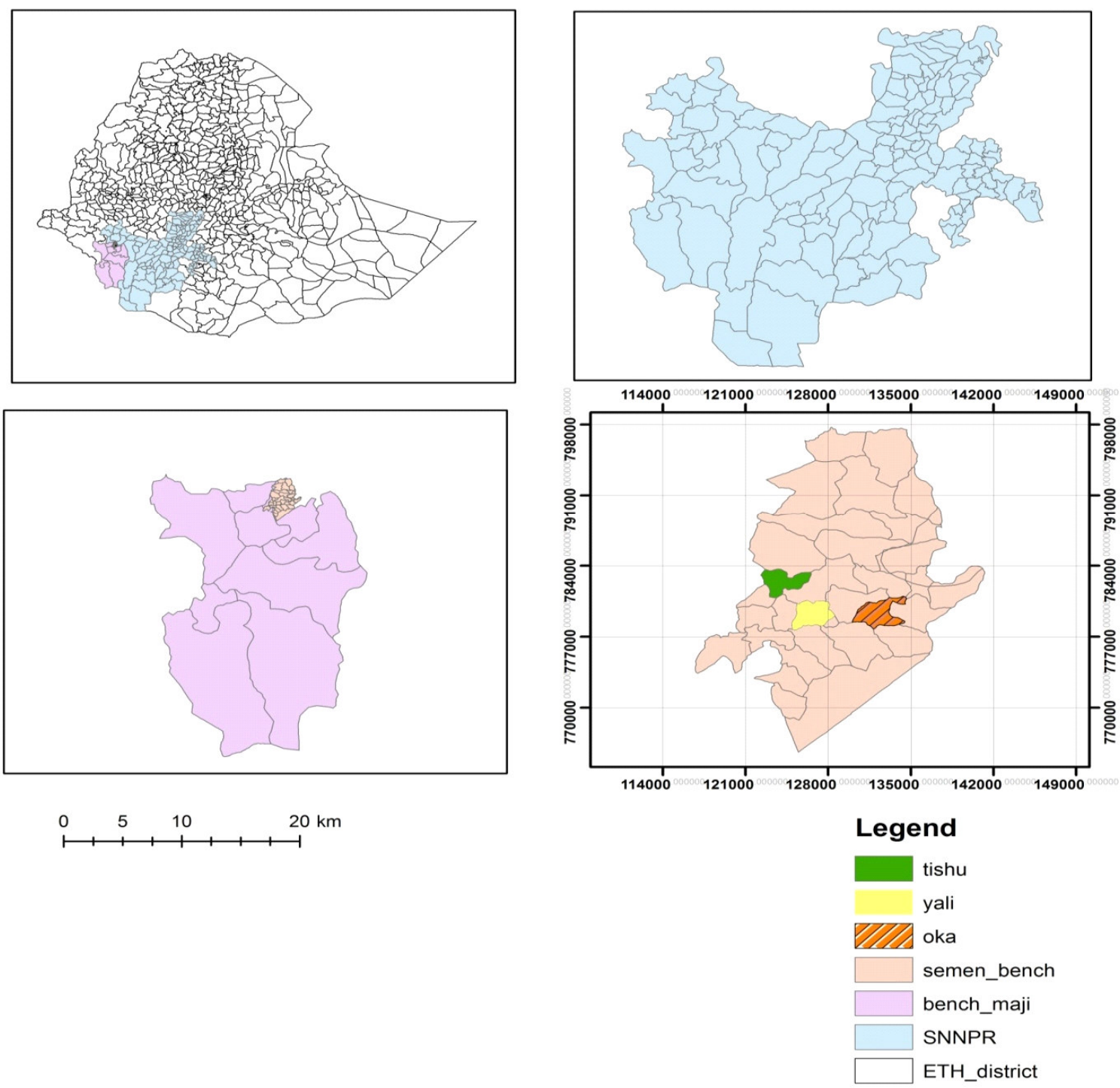

Figure 1: map of the study area

\subsection{Sampling Procedures}

Multi-stage sampling method was applied to select sample respondents to study motives and factors affecting rural households saving. First, purposive sample selection method was used to select the district. The bases of stratification of the villages was distance and villages located $10 \mathrm{~km}$ away from the financial institutions is considered as nearby villages whereas villages located above $10 \mathrm{~km}$ are taken as remote villages. Thereafter, four villages, two from the nearby and two from the remote (far-away villages) were selected randomly. In the third stage, the rural households in each village were stratified into saving and non-saving households. Then sample was selected randomly from saver and non- saver household heads.

\subsection{Sample size determination}

Sampling is one of the methods, which allows the researcher to study a relatively small number of units representing the whole population (Kaba, 2009) The sample size for collecting quantitative data for this research is determined by using the Yamane (1967) formula which is more conducive and match with the situation due to time and financial constraints. Accordingly, 178 samples were taken from the district to carry out this work.

\subsection{Data Types and Sources}

Both qualitative and quantitative data were collected from both the primary and secondary sources through different methods. 
The primary data were collected through household survey from the selected sample. The primary data included information related to demographic characteristics, economic, institutional factor of the households. Interview was used as a method of data collection for the objectives to collect quantitative data, whereas key informant, focus group discussion and direct personal observation used for collection of qualitative data. Secondary data were collected from relevant government offices of the district especially from agricultural office, Microfinance Institutions (MFIs). Furthermore, different published and unpublished documents and literatures related to the research problem were reviewed to articulate the survey result.

\subsection{Methods of Data Collection}

For this study, both qualitative and quantitative approaches were employed. Qualitative data were collected using focus group discussions, key informant interviews and field observation while household survey (using semistructured questionnaire) was used to collect quantitative data.

\subsubsection{Key Informant Interview}

Key informant interviews were conducted with purposively selected experts and local leaders. The potential respondents of key informants were experts from district micro finance office, micro-finances agents working in each selected villages from agricultural development agents working in each villages and villages administrators.

\subsubsection{Focus Group Discussion (FGD)}

Focus group discussions (FGDs) were carried to collect qualitative data with the aim to supplement and augment the data obtained from the main household survey. Checklist questions were prepared to capture the divergent idea on a common purpose. Focus group discussions were held with 8 groups, 2 in each village. For FGD, a team having 6 to 8 members (representatives of the groups) was purposively selected from homogenous groups. The discussion participants included participants from different age group, literacy and economic status to come with different views.

\subsection{Methods of Data Analysis}

The data analysis method was selected based on the nature of the data and objective of the study. The households' data was analyzed using descriptive statistics model to draw meaningful inferences about the problem under investigation. Microsoft Office Excel 2010, Statistical Package for Social Science (SPSS) version 20 and stata version 14 were used as tools for data entry and analysis.

\subsubsection{Descriptive statistics and binary logit model}

After the organization of the quantitative data, descriptive analysis was used to have clear picture of the sample units. The descriptive statistics such as Percentages, frequencies, mean and standard deviation was employed for demographic variables and to identify the motivating factors of rural households saving. In addition, chi-square test was used in identifying the relationship between rural households saving status and dummy independent variables and t-test was used to test the differences between rural households saving status and continuous independent variables. Binary logit model was applied to analyze factors affecting the saving status of the households in the area. The qualitative data were gathered from the key informant interview and focus group discussion was narrated to articulate the quantitative data.

\section{Result and Discussion}

\subsection{Demographic characteristics of sample respondents}

\subsubsection{Age of household heads}

As shown in Table 1 below, the average age of selected household head in the study areas was 32.81 and the standard deviation was 7.536. It also reveals that the mean difference in age between the two groups namely savers and non-savers was 32.815 . The $\mathrm{t}$-value $(\mathrm{t}=58.092 ; \mathrm{p}=0.000)$ showed that there was a statistically significant mean difference in age between savers and non-savers household heads.

Table 1: age of household heads

\begin{tabular}{lllllll}
\hline $\begin{array}{l}\text { Continuous } \\
\text { variable }\end{array}$ & $\begin{array}{l}\text { Number of } \\
\text { observation }\end{array}$ & Mean value & Std.deviation & $\begin{array}{l}\text { Mean } \\
\text { difference }\end{array}$ & t-value & p-value \\
\hline Age of HH & 178 & 32.81 & 7.536 & 32.815 & 58.092 & $0.000^{* *}$ \\
\hline
\end{tabular}

Source: computed from own survey data (2019)

\subsubsection{Gender of household heads}

Gender or sex of household head is one of the variables that can determine rural households' savings. As indicated in Table 2, out of the sampled household heads 123 (69.10\%) were male headed households and the remaining 55 $(30.90 \%)$ were female headed households. From a total 178 sampled household heads, 42 (35\%) of the non-savers were female headed households where as $78(65 \%)$ of the non-savers were male headed households. The result revealed that male headed saver and non-saver households had greater percentage than female headed households. Based on Table 2, the chi- square value $\left(x^{2}=2.9010 ; \mathrm{P}=0.089\right)$ showed that there was no statistically significant association between saving status and sex of saver and non-saver households. This implies that being male or 
female headed household had no statistically significant influence on saving decision of the households.

Table 2: Chi square test for gender of household heads

\begin{tabular}{llll}
\hline Saving status of HH & \multicolumn{2}{c}{ Gender of $\mathrm{HH}$} & Total \\
& Female & Male & \\
\hline Non saver & 42 & 78 & 120 \\
& 35 & 65 & 100 \\
& 76.36 & 63.41 & 67.42 \\
\hline Saver & 13 & 45 & 58 \\
& 22.41 & 77.59 & 100 \\
& 23.64 & 36.59 & 32.58 \\
\hline Total & 55 & 123 & 178 \\
& 30.90 & 69.10 & 100 \\
& 100 & 100 & 100 \\
\hline
\end{tabular}

Pearson Chi2 $(1)=2.9010 \quad \operatorname{Pr}=0.089$

\subsubsection{Family size of household heads}

Family size of rural household heads is also one of the main determinants of saving status of household heads in many literatures. The mean family member of household heads in the selected areas of North Bench Maji district was 4.76 with 1.799 standard deviation. The mean difference in family size between savers and non-savers household head was 4.758 . The $t$-value $(t=35.296 ; \mathrm{p}=0.000)$ reveals that there was a statistically significant mean difference in family size among saver and non-saver household heads in the North Bench district. The implication here is that the less the number of family number, the high saving capacity of the household.

Table 3: family size of household heads

\begin{tabular}{llllllll}
\hline $\begin{array}{l}\text { Continuous } \\
\text { variable }\end{array}$ & $\begin{array}{l}\text { Number } \\
\text { observation }\end{array}$ & of & $\begin{array}{l}\text { Mean } \\
\text { value }\end{array}$ & Std.deviation & $\begin{array}{l}\text { Mean } \\
\text { difference }\end{array}$ & t-value & p-value \\
\hline $\begin{array}{l}\text { Family size } \\
\text { HHs }\end{array}$ & 178 & 4.76 & 1.799 & 4.758 & 35.296 & $0.000^{* *}$ \\
\hline
\end{tabular}

Source: computed from own survey data (2019)

3.1.4. Education level of household heads

The chi-square value $x^{2}=1.0199 ; p=0.03$ ) of the sampled households indicated that there was statistically significant difference in the education levels of savers and non-savers (Table 4). As revealed from the survey result in Table 4, from a total of 58 saver household heads, 37(63.79\%) were literate household heads and the remaining 21(36.21\%) were illiterate saver household heads. This indicates that household heads saving status in the formal financial institution increases when household heads level of education increases. This finding was in line with the findings of (Girma et al. 2014; Aron et al., 2013). But, contrary to the finding of Sebhatu (2012) who discovered that education and rural households' savings had negative relationship as saving schemes might not need good educational background of the respondents.

Table 4: Chi square test for education level of household heads

\begin{tabular}{llll}
\hline Saving status of HH & \multicolumn{2}{l}{ Educational status of $\mathrm{HH}$} & Total \\
& Illiterate & Literate & 120 \\
\hline Non saver & 67 & 53 & 100 \\
& 55.83 & 44.17 & 67.42 \\
\hline Saver & 64.42 & 71.62 & 58 \\
& 21 & 37 & 100 \\
& 36.21 & 63.79 & 32.58 \\
\hline Total & 28.38 & 35.58 & 178 \\
& 74 & 104 & 100 \\
& 41.57 & 58.43 & 100 \\
\hline
\end{tabular}

Pearson Chi2 $(1)=1.0199 \quad \operatorname{Pr}=0.031$

\subsection{The motives of households to save}

As shown in Table 5, a large number of saver household heads 20(34.48\%) were saving their money income in the formal financial institutions in order to meet any emergency or contingency that might occur in the future period and a very few number of saver household heads $5(4.14 \%)$ were saving their money income in the formal financial institutions to start their own business in the future time. Taking investment opportunities, starting own business and trying to have long term assets were not the main goal of saving in the formal institutions among rural households. Therefore, the main purpose of saving in the formal institutions among rural household was not for long run plan or purpose rather to run short run activities. 
Table 5: The motives of rural households to save

\begin{tabular}{lll}
\hline Motives & Frequency & Percentage \\
\hline To mitigate any emergency or contingency that might occur in the future period & 20 & 34.48 \\
\hline To smooth future consumption & 15 & 25.86 \\
\hline Due to rising money value from saving, i.e., interest rate & 8 & 13.8 \\
\hline To have luxury life & 10 & 17.24 \\
\hline To start own business & 5 & 8.62 \\
\hline
\end{tabular}

Computed from own survey (2019)

\subsection{Reasons for not to save}

As understood from the survey result, from a total of 120 sampled non-saver household heads in the study area, proportional number of household heads were confirmed that they were not saving in formal financial institutions due to lack of surplus income, limited access to banks and other formal financial institutions in the area and due to insignificant (low) interest rate provided by formal institutions. As shown in Table 6, the majority of non-saver household heads conformed that they were not saving their income in the formal financial institutions due to lack of surplus income in the form of cash, shortage of banks and other formal institutions in the area and low interest rate whereas a few of them stated that they were not saving in the formal financial institutions due to high inflation rate and lack of saving awareness.

Table 6: Reasons for not to save

\begin{tabular}{lll}
\hline Reasons for not saving & Frequency & Percentage \\
\hline Lack of surplus income to save & 30 & 25 \\
\hline Due to high inflation rate & 10 & 8.33 \\
\hline Limited access to FFI in the area & 30 & 25 \\
\hline Lack of awareness about saving culture & 20 & 16.67 \\
\hline Insignificant interest rate & 30 & 25 \\
\hline
\end{tabular}

Computed from own survey (2019)

\subsection{Factors affecting rural households saving behavior}

The dependent variable, households' saving status has a dichotomous nature taking the value of 1 if the household heads save in formal financial institutions, and 0 for non-savers. Binary logit model identifies characteristics that initiate households to save in the banks and other microfinance institutions as opposed to those who do not. Before running the Binary logit model, different tests were carried out. To check the existence of co-linearity among continuous independent variables, variance inflation factor VIF (Variance Inflation Factor) was used. The rule of thumb states that if the VIF of a variable exceeds 10 , which will happen if $\mathrm{R}^{2}$ exceeds 0.90 , that variable is said to be highly collinear or shows the existence of multicollinearity problem in the regression analysis and should be removed from the regression analysis. As already revealed in the VIF Table 7 below, the value of VIF for all explanatory variables is less than 10 and this reveals that there is no serious multicollinearity problem among the explanatory variables used in this regression analysis (Gujarati, 2009).

Table 7: Variance Inflation Factor (VIF)

\begin{tabular}{lll}
\hline Variable & VIF & 1/VIF \\
\hline Family size & 1.72 & 0.579728 \\
\hline Livestock ownership & 1.53 & 0.651729 \\
\hline Landholding size & 1.43 & 0.697149 \\
\hline Age & 1.42 & 0.703950 \\
\hline Total annual expenditure & 1.34 & 0.745423 \\
\hline Total annual income & 1.27 & 0.787217 \\
\hline Interest rate & 1.14 & 0.874148 \\
\hline Distance to financial institutions & 1.12 & 0.896635 \\
\hline Market distance & 1.06 & 0.939852 \\
\hline Transaction cost & 1.06 & 0.943207 \\
\hline Mean VIF & 1.31 & \\
\hline
\end{tabular}

\section{Source: own survey (2019)}

Similarly, the existence of multicollinearity problem among dummy independent variables was checked by using contingency coefficients. The decision rule states that when the value of contingency coefficients approaches to 1 , it reveals the presence of multi-collinearity problem among the discrete independent variables, whereas, 
values less than 0.75 shows there was no serious collinearity problem among discrete independent variables used in the regression analysis. From Table 8 , it could be seen that all the values of the contingency coefficients computed showed that there was no serious collinearity problem among the dummy explanatory variables used in this regression analysis.

Table 8: Contingency Coefficients

\begin{tabular}{llllll}
\hline Variables & SEX & MARTS & EDUL & ACEXT & ACCRT \\
\hline SEX & 1 & & & & \\
\hline MARTS & 0.326 & 1 & & & \\
\hline EDUL & 0.173 & 0.141 & 1 & 1 & \\
\hline ACEXT & 0.011 & 0.088 & 0.084 & 0.219 & 1 \\
\hline ACCRT & 0.191 & 0.005 & 0.209 & & \\
\hline
\end{tabular}

Source: own survey (2019)

As understood from Table 9, the binary logit model was found to be significant at 5\% significance level. Out of the 14 independent variables; seven of the variables which are clearly interpreted followed by the logistic regression table were found to be statistically significant while the remaining (gender of heads of household, family size of household head, market distance, distance from the formal financial institutions, land ownership of heads of household, total annual income and annual expenditure of heads) were not statistically significant in explaining the variations in the dependent variable that is the saving status of household heads in the study area due to change in independent variables.

Table 9: Logistic regression, Coefficients

Logistic regression

$$
\begin{array}{ll}
\text { Number of obs } & =178 \\
\text { Wald chi2 (14) } & =75.84 \\
\text { Prob }>\text { chi2 } & =0.000 \\
\text { Pseudo R2 } & =0.7076
\end{array}
$$

\begin{tabular}{|c|c|c|c|c|c|c|}
\hline Saving status & Coef. & Robust Std.Error & $\mathrm{Z}$ & $\mathrm{p}>/ \mathrm{z} /$ & \multicolumn{2}{|c|}{$[95 \%$ conf.interval] } \\
\hline Age & -0.1076199 & 0.0439223 & -2.45 & $0.014 * * *$ & -0.1937059 & 0.0215338 \\
\hline Gender & -0.9305313 & 0.6201362 & -1.50 & 0.133 & -2.145976 & 0.2849133 \\
\hline Family size & -0.0722028 & 0.1780571 & -0.41 & 0.685 & -0.4211883 & 0.2767827 \\
\hline Education level & 1.98488 & 0.7903031 & 2.51 & $0.012 * * *$ & 0.4359143 & 3.533846 \\
\hline Credit access & 1.99624 & 0.748404 & 2.67 & $0.008 * * *$ & 0.5293949 & 3.463085 \\
\hline Extension service utilization & 2.806587 & 0.6044348 & 4.64 & $0.000 * * *$ & 1.621917 & 3.991257 \\
\hline Market distance & -0.0346186 & 0.1106175 & -0.31 & 0.754 & -0.2514248 & 0.1821877 \\
\hline Distance from FFI & -0.0099529 & 0.0308917 & -0.32 & 0.747 & -0.0704996 & 0.0505937 \\
\hline Interest rate & 3.233451 & 0.6188228 & 5.23 & $0.000 * * *$ & 2.020581 & 4.446321 \\
\hline Transaction cost & 0.0193608 & 0.004592 & 4.22 & $0.000 * * *$ & 0.0103606 & 0.028361 \\
\hline Land ownership of $\mathrm{HH}$ & -0.4380607 & 0.5069318 & -0.86 & 0.388 & -1.431629 & 0.5555074 \\
\hline Livestock ownership of $\mathrm{HH}$ & 0.4881306 & 0.230273 & 2.12 & $0.034 * * *$ & .0368039 & 0.9394573 \\
\hline Total annual income & 0.0000481 & 0.000033 & 1.46 & 0.144 & -0.0000165 & 0.0001127 \\
\hline Total annual expenditure & -0.0000303 & 0.0000607 & -0.50 & 0.618 & -0.0001493 & 0.0000888 \\
\hline -Cons & -1.974815 & 1.98962 & -0.99 & 0.321 & -5.874398 & 1.924768 \\
\hline
\end{tabular}

Log pseudo likelihood $=-45.214203$

Model outputs (2019), $* * *=$ statistically significant at 5\% significance level 
Table 10: Logistic regression, Odds ratio

Logistic regression

\begin{tabular}{|c|c|c|c|c|c|c|}
\hline Log likelihood $=-45.214203$ & & & $\begin{array}{l}\text { Numbe } \\
\text { LR chi } \\
\text { Prob }>\text { c } \\
\text { Pseudo }\end{array}$ & (4) & $\begin{array}{l}=178 \\
=134.28 \\
=0.000 \\
=0.7076\end{array}$ & \\
\hline Saving status & Odds Ratio & $\begin{array}{l}\text { Robust } \\
\text { Std.Error }\end{array}$ & $\mathrm{Z}$ & $\mathrm{p}>/ \mathrm{z} /$ & {$[95 \%$ conf. } & terval] \\
\hline Age & 0.8979689 & 0.0453843 & -2.13 & 0.033 & 0.813281 & 0.9914753 \\
\hline Gender & 0.3943441 & 0.2616897 & -1.40 & 0.161 & 0.1074018 & 1.447902 \\
\hline Family size & 0.9303422 & 0.161828 & -0.42 & 0.678 & 0.6615777 & 1.308292 \\
\hline Education level & 7.278174 & 5.24429 & 2.75 & 0.006 & 1.772919 & 29.8783 \\
\hline credit access & 7.361324 & 4.776834 & 3.08 & 0.002 & 2.063494 & 26.26085 \\
\hline Extension service utilization & 16.55332 & 12.15605 & 3.82 & 0.000 & 3.924636 & 69.81858 \\
\hline Market distance & 0.9659738 & 0.1288364 & -0.26 & 0.795 & 0.7437666 & 1.254567 \\
\hline Distance from FFI & 0.9900964 & 0.0368607 & -0.27 & 0.789 & 0.9204237 & 1.065043 \\
\hline Interest rate & 25.36705 & 23.5897 & 3.48 & 0.001 & 4.099285 & 156.9754 \\
\hline Transaction cost & 1.019549 & 0.0042747 & 4.62 & 0.000 & 1.011205 & 1.027962 \\
\hline Land ownership of HH & 0.6452866 & 0.3062067 & -0.92 & 0.356 & 0.2545854 & 1.63558 \\
\hline Livestock ownership of $\mathrm{HH}$ & 1.629268 & 0.419488 & 1.90 & 0.058 & 0.9836336 & 2.698681 \\
\hline Total annual income & 1.000048 & 0.0000377 & 1.28 & 0.202 & 0.9999743 & 1.000122 \\
\hline Total annual expenditure & 0.9999697 & 0.0000605 & -0.50 & 0.617 & 0.9998512 & 1.000088 \\
\hline- Cons & 0.138787 & 0.3205001 & -0.86 & 0.392 & 0.001502 & 12.82402 \\
\hline
\end{tabular}

Log likelihood $=-45.214203$

Model outputs (2019)

\subsection{Interpretation of model results}

Demographic, socio-economic and institutional variables are the major explanatory variables expected to influence the saving decision of rural household heads in the study area. According to (Gujarat, 2003) the goodness of fit in logit model was measured by using likelihood ratio test that states chi-square distribution with degree of freedom (df) equal to number of independent variables included in the model. All 178 observations used in the binary logit model appeared at the top of binary logit model output showed that none of the variables have been missed. The binary logit model as a whole fits significantly better than an empty model or a model with no explanatory variables as indicated by likelihood ratio chi-square of 134.28 with a $(p$-value $=0.000)$. In this research paper, odds ratio were used to understand the effect of a predicator variable on the response variable that is rural households saving status in the study area. Odds ratio that exceeds one revealed that the event is more likely to occur as the predictor increases whereas odds ratio that are less than one indicate that the event is less likely to occur as the predictor increases.

The following seven explanatory variables (age, the level of education, credit service access, utilization of agricultural extension service, the rate of interest, transaction cost and livestock ownership of heads of households) used in the binary logit model were found to be statistically significant in explaining the dependent variable that is the saving behavior.

\subsubsection{Age of household heads}

One of the crucial factors in determining the rate of saving by a household was age of household heads. As the model result on Table 10 shows, age of heads of household is statistically significant at $5 \%$ significant level and negatively influences the saving decision of household heads in the North Bench district. Based on the binary logit model result, aged household heads had 0.8979689 times less odds ratio of saving than younger or middle aged household heads. The possible reason might be the anxiety of a fall in income of household head when they are getting aged or retired. This finding was similar with Gedela (2012) who stated that age of household head has a negative and statistically significant influence on the saving decision of household heads and Halefom (2015) who revealed that there was some difference in average saving across different age groups. But this finding was in contrast to Bogale et al. (2017) who found empirical evidence on a positive and statistically significant influence of age on household's saving decision.

\subsubsection{Education level of household heads}

Individual's ability to process information received from any source increases with their increased educational status. As understood from the model result, the level of education of rural households positively and statistically significantly influencing the saving decision of rural households at $5 \%$ significant level. The result of the model revealed that literate household heads had 7.278174 times more odds-ratio of saving than illiterate household heads. The possible explanation for this is that education helps the household head's to save in formal financial institutions due to the analytical capacity created would support them to analyze, interpret and identify the advantage of saving in the formal financial institutions than illiterate household head's. This finding is in contrast to the finding of 
(Tsega and Yemane, 2014) that showed the negative contribution of educational level to the households saving decision but in line with the findings of (Michael, 2013; Girma et al. 2013) who found a positive and statistically significant influence of the level of education on the saving decision of household heads.

\subsubsection{Access to credit of household heads}

On citrus par bus condition, access to credit might enhance the productive capacity of household heads and might enable them to generate more money income that would increase household's motivation to save in the formal financial institutions. Based on the model result in Table 10 above, access to credit of household head had a positive and statistically significant influence on the saving decision of household heads in the study area. The likelihood of rural households with access to credit relative to the base category increased by 7.361324 when access to credit increases on citrus par bus condition. This implies that rural households with more access to credit would have higher tendency to save more money income in the formal financial institutions than another households who did not had access to credit service. This finding was similar to (Obayelu, 2012; Girma et al. 2013), but contrary to Adeyeno and Baire (2005) that showed a negative and insignificant association between credit access and rural households saving status.

\subsubsection{Utilization of agricultural extension service}

As understood from the binary logit model, utilization of agricultural extension service positively and statistically significantly affecting the saving decision of rural households in the study area. Holding all other factors constant in the model, the likelihood of rural households with access to agricultural extension service relative to the base category increased by a factor of 16.55332 when access to agricultural extension service increases. This finding was in line with Girma et al. (2013) who found that contact with extension agents increases the level of household savings by 109.29 .

\subsubsection{Interest rate in formal financial institutions}

One of the main determinants related with saving institutions that can influence the saving decision of rural households was the rate of interest or the rate of return on saving. The model result indicates that when interest rate increases, rural household heads were more likely to save their money income in the formal financial institutions. Based on the model result, holding all other factors constant in the model, the odds ratio increased by a factor of 25.36705 when interest rate increased by 1 unit. This result possibly indicates that high interest rate motivates rural households to save in the formal financial institutions. This finding is in line with the findings of (Kibet et al. 2009; Nayak 2013; Aron et al. 2013).

\subsubsection{Transaction cost incurred during saving process}

Cost of information and food incurred during depositing money income in the formal financial institutions were expected to negatively influence the saving decision of rural households. As understood from the model result (Table 10), transaction cost had a positive and significant effect on the saving decision of rural household heads in the study area. Here, holding all other factors constant in the model, the odds ratio increased by a factor of 1.019549 when transaction cost increases by 1 unit. According to this survey result, high transaction cost attracts rural households to save in the formal financial institutions. This finding was in contrary with the finding of Nayak (2013) who found that low transaction costs can motivate rural household heads to save their money income in the formal financial institutions.

\subsubsection{Livestock ownership of household heads}

Majority of rural households in Ethiopia in general and in North Bench Maji district in particular are herding livestock's as their permanent asset and as the major means of generating household's income. As understood from the model result (Table, 10), when livestock ownership increases by one unit, the odds ratio of saving increases by a factor of 1.629268. Rural household heads were more likely to save in the formal financial institutions when the odds ratio of saving resulted from one unit increase in the livestock ownership exceeds one. This result was similar with Girma et al. (2013) who stated that livestock holdings statistically significant and positive effect on the amount of households saving.

\section{Conclusions and Recommendations}

\subsection{Conclusions}

This study was attempted to address the motives of rural household's saving and factors affecting their saving behavior in North Bench district, southern Ethiopia. It was investigated that the status of rural households' saving that was remained below standard even if the five top motives of saving in the area have been smoothly forcing the households to save their money income in the formal financial institutions. This has resulted to have majority $(67.42 \%)$ who could not save their money in any of the institutions. Reasons for the degraded motives of households saving in the study area are lack of surplus income, inflation, lack of awareness about pros and cons of saving in formal institutions, less accessibility to formal financial institutions and low rate of return on saving whereas mitigating any emergency or contingency, smoothing future consumption or expenditure of rural household heads, to have rising money value from saving, to have luxury life in the future and planning to start new business in the future are taken as motivating factors of saving in the area. 
From the binary logit model result, we discovered that age of household heads as one of the factor that influences saving decision of rural households negatively and statistically significant influence on the saving decision of rural household heads whereas all the other factors including access to credit service, level of education, utilization of agricultural extension service, the rate of return on saving and transaction cost and livestock ownership have positively and statistically significantly influencing the saving decision of rural household heads in the study area.

\subsection{Recommendations}

Based on the core findings of this paper, the following recommendations were forwarded for all concerned bodies including the government.

- Since educated rural households were more likely to save their money income in the formal financial institutions, priority should be given to adult education by all concerned bodies to enhance the analytical capacity and awareness of rural households towards saving culture.

- Priorities should be given to diversify income sources of rural household's in the study area since lack of money income in the form of cash prohibits rural households of North Bench district to save in the formal financial institutions.

- To minimize problems related with lack of easy access to financial institutions in the study area, both government and private banks should expand their branches in the North Bench district.

- As long as access to credit and utilization of agriculture extension service positively and statistically significantly influencing the saving decision of rural households in the study area, all the concerned bodies should provide conducive environment to rural families to have easily access to credit and contact with agricultural extension agents to increase saving in the formal financial institutions.

\section{Reference}

Abdelkhalek Touhami, Arestoff Florence, Defreitas Mekkaoui and Mage Sabine .(2009). A Micro econometric Analysis of Households Saving Determinants in Morocco. University of Paris, France.

Abdelkhalek Touhami, Arestoff Florence, Defreitas Mekkaoui and Mage Sabine .(2009). A Micro econometric Analysis of Households Saving Determinants in Morocco. University of Paris, France.

Adeyeno R and Baire As. (2005). Saving and Investment patterns of Cooperative Farmers in South Western Nigeria. Journal of Social Science, 11(3):183-192

Annual report of North Bench District administrative office (2019)

Aron Haileslassie, Nigus Abera, Getnet Baye. (2013). Assessment of Saving Culture among m Households in Ethiopia. Journal of Economics and Sustainable Development, 4 (15):1

Banking the poor via savings accounts: Evidence from afield experiment Silvia Prina, Journal of Development Economics 115 (2015) 16-31

Beauro of Finance and Economic Development. (2012). annual statistical abstract data of Southern Nation Nationalities and Peoples Regional State

Bogale Yadeta, Amsalu Bedemo and Melikamu Belina. (2017). "Determinants of Saving Behavior of Farm Households in Rural Ethiopia: The Double Hurdle Approach".

Gedela Surya Prakasa .(2012). Determinants of Saving Behavior in Rural and Tribal Households: An Empirical Analysis of Visakhapatnam District, International Journal of Research in Social Sciences, 2(8).

Girma Teshome, Belay Kassa, Bezabih Emana, and Jema Haji. (2014). Saving patterns of rural households in East Hararghe. Journal of Development and Development Economics, 6(4):177-183.

Girma, T., Belay, K.; Bezabih, E. and Jema H., (2013). Determinants of Rural Household Savings in Ethiopia: The Case of East Hararghe Zone, Oromia Regional State. Journal of Economics and Sustainable Development, Vol.4, No.3, 2013

Gujarati, D. N. (2009). Basic econometrics, Tata McGraw-Hill Education.

Gujarati, DN. (2003). Basic econometrics. Fourth Edition. McGraw-Hill, New York.

Halefom, .Y. (2015). "Determinants of household saving in Gedeo zone, Southern Ethiopia". Journal of Economics and Sustainable Development, 6 (7).

Harris Mark, Loundes Joanne and Elizabeth Webster. (1999). Determinants of Household Saving in Australia.

Kibet, 1.K., Mutai, B. K., Ouma, S. and Owuor, G. (2009). "Determinants of household saving: Case study of smallholder farmers, entrepreneurs and teachers in rural areas of Kenya", Journal of Development and Agricultural Economics, 1 (7), 137-143.

Kifle Tesfamariam. (2012). Determinants of Saving Behavior of Cooperative Members Survey Evidence from Tigrai Region, Ethiopia. Journal of Research in Economics and International Finance, 1(5) : 150-158.

Kifle Tesfamariam. (2012). Saving Behavior and Determinants of Saving Mobilization by Rural Financial Cooperators Mekelle University, Ethiopia. Journal of Agribusiness and Rural Development, 4 (26): 129-146 Michael, K. (2013). "Savings habit and use of savings among households in Ga-East municipality", Dissertation 
submitted to the University of Ghana, Legon in partial fulfillment of the requirement for the award of a master of philosophy development studies degree.

Mirach, T. H. and Y. M. Hailu (2014). "Determinants of household savings in Ethiopia: A case of North Gondar

Nayak, S. (2013). "Determinants and pattern of saving behavior in rural households of western Odisha", a thesis submitted for the partial fulfillment of the master degree in development studies. National Institute of Technology, India, 25-28.

Obayelu OA. (2012). Saving Behavior of Rural Households in Kawara State, Nigeria. African Journal of Basic Applied Science, 4(4):115-123.

Rha, Jong-Youn, Catherine P. Montalto, and Sherman D. Hanna. (2006). The effect of self-control mechanisms on household saving behavior. Financial Counseling and Planning 17: 3-16.

Sebhatu Kifle Tesfamariam .(2012) "Saving Behavior and Determinants of Saving Mobilization by Rural Financial Co-operators in Tigray Region, Ethiopia: Journal of Agribusiness and Rural Development".

Shahab e Saqib. (2016). Determinants of Household Savings in Rural and Urban Areas: The Case of Chitral District, Pakistan, International Journal of Academic Researchin Business and Social Sciences March 2016, Vol. 6, No. 3

Tadele, M. (2018). "Household saving behavior in Jimma zone of Oromia Region, Ethiopia", International Journal of Research in Commerce, It and Management, 5(3).

Tarekegn Tariku.(2018). Saving Practices of Rural Households in Ethiopia: Case of East Gojjam Zone, Amhara Regional State, Journal of Economics and Sustainable Development Vol.9, No.9, 2018

Tsega Hagos and Yemane Michael .(2014). Determinants of household saving in Ethiopia: A case of North Gondar Zone, Amhara Regional State, Ethiopia. International Journal of Development and Economic Sustainability, 2(4): 37-49.

Yao, R., Wang, F., Weagley, R. O., Liao, L. (2011). Household saving motives: Comparing American and Chinese consumers. Family and Consumer Sciences Research Journal, (1): 28-44.

Zone, Amhara regional state." International Journal of Development and Economic Sustainability2(4): 37-49. 